\title{
EVALUASI KINERJA GURU DALAM PENINGKATAN MUTU PENDIDIKAN DI YAYASAN AL KENANIYAH JAKARTA TIMUR
}

\begin{abstract}
Mas Ning Zahroh*
Abstract: Theoretically the results of the discussion of this research is expected to provide scientific contributions to the development of science, to provide some suggestions to the school and other schools in terms of teacher performance in improving the quality of education, to be the evaluation for Yayasan Pondok Al Kenaniyah to provide better service in the quality of their education. This study is also expected to be the contribution for the researcher in the field of education. This study uses a qualitative method of data collection. The data is achieved by conducting interviews, observation and checklist. The data is obtained to analyze the performance of teachers in improving the quality of education with the subject of 60 people in Yayasan Al Kenaniyah, East Jakarta to investigate. Based on the data obtained can be summarized as follows: regarding to the performance of teachers in the learning plan, the performance of teachers in the implementation of learning, the performance of teachers in the assessment of learning outcomes, also discipline of the teachers in performing their duties to get good performance. Thus, the quality of education will be better in the future.
\end{abstract}

Keyword : Evaluation, Teacher Performance, quality improvement.

\section{PENDAHULUAN}

Salah satu faktor utama yang sangat menentukan dalam meningkatkan mutu pendidikan adalah tersedianya guru profesional yang mampu melaksanakan tugas pembelajaran dengan penuh tanggung jawab. Pada kenyataanya guru belum memiliki profesionalisme yang memadai untuk menjalankan tugasnya sebagaimana disebut dalam pasal $39 \mathrm{UU}$ No 20/2003 yaitu merencanakan pembelajaran, melaksanakan pembelajaran, menilai hasil pembelajaran, melakukan pembimbingan, melakukan pelatihan, melakukan penelitian dan melakukan pengabdian masyarakat. Hal ini disebabkan guru menduduki posisi yang sangat strategis dan sebagai ujung tombak dalam keberhasilan proses pembelajaran. Guru berposisi sebagai perancang, pelaksanaan dan pengevaluasi pembelajaran sehingga tidak berlebihan apabila guru dikatakan merupakan salah satu orang yang bertanggung jawab dalam menyukseskan proses pembelajaran. Sebagai bagian dari upaya peningkatan mutu pendidikan, maka perlu dilakukan evaluasi kinerja guru. Evaluasi kinerja guru cenderung belum rutin dilakukan. Evaluasi kinerja guru dimaksudkan untuk: (1) merumuskan kriteria dan acuan kinerja guru, (2) melakukan penilaian, (3) mencocokan hasil penilaian kinerja dan kriteria, dan (4) menyusun rekomendasi.

Namun realita menunjukan bahwa keberadaan guru masih jauh dari harapan. Kondisi ini berdampak pada pencapaian kualitas pendidikan terganggu. Yayasan Alkenaniyah merupakan lembaga pendidikan yang berdiri ditengah-

* Guru Di SMP Syahid 1 Jakarta 
tengah kota Jakarta, sekolah yang berada di dalam naungan Yayasan ini yaitu Madrasah Tsanawiyah dan Madrasah Aliyah. Dalam usaha perbaikan mutu pendidikan maka perlu dilakukan upaya untuk mengetahui gambaran kinerja guru guna menemukan langkah-langkah dalam meningkatkan kinerja guru. Untuk mengetahui gambaran objektif kinerja guru dalam peningkatan mutu pendidikan

Menurut Lincoln dalam Zainal Arifin (2009:5) "evaluation is a process for describing an evaluand and judging its merit and worth. Evaluasi adalah suatu proses untuk menggambarkan peserta didik dan menimbangnya dari segi nilai. Sedangkan Derek Torington, dkk (2005:619) mendefinisikan evaluasi "job evaluation is concerned with assesing the relatif demands of different jobs within an organization. Its usual purpose is ti provide a basis for relaying differences in rates of pay to different in job requirements. It is therefore a tool which can be used to help in the determination of a pay structure". Evaluasi pekerjaan terkait penilaian tuntutan relative dari pekerjaan berbeda dalam organisasi. Itu biasanya bertujuan dalam menyediakan dasar mengenai perbedaan terkait bayaran dengan tugas pekerjaan. Evaluasi pekerjaan penilaian cara seseorang atau sekelompok orang dalam bekerja, hal ini penting dilakukan terutama sebagai acuan dalam penentuan pelaksanaan pengupahan. Sehingga evaluasi merupakan alat yang dapat digunakan untuk membantu menentukan struktur pengupahan.

Malcom Provus (2015:5) mendefinisikan "evaluation is the process of agreeing upon program standard, determining wheter a disrepancy exists between some aspect of the program and standard governing that aspect of the program and using disrepancy information to identify weaknesses of the program. Evaluasi yang berarti menilai kesenjangan antara standart yang di tetapkan dengan program yang terlaksana di lapangan untuk mengetahui kelemahan dari suatu program tersebut dan dilakukan perbaikan program. Arti dari beberapa istilah yang telah dijelaskan di atas tentang evaluasi, maka dapat disimpulkan bahwa pada hakekatnya evaluasi adalah suatu proses yang sistematis dan berkelanjutan untuk menentukan kualitas dari sesuatu berdasarkan pertimbangan dan kriteria tertentu dalam rangka pembuatan keputusan.

Pengertian kinerja dikemukakan Beery Staw (2003:205) "performance is defined as the output of an individual or team that is decipted in their on description and for which they ". Kinerja didefinikan output individu atau tim yang tergambar dalam uraian kerjanya dan untuk itu mereka dibayar berdasarkan nilai kinerjanya atau sejenisnya. Jennifer M George, Gareth R Jones (2012:159) bahwa "performance is an evaluation of the result of the persons behavior: it involves determning how well or poorly a person has accomplished a task done a job". Kinerja adalah suatu evaluasi hasi perilaku seseorang. Hal ini meliputi penentuan seberapa bagus atau kurangnya seseorang menyelesaikan tugas atau pekerjaan dilaksanakan.

Pendapat lain mengenai kinerja dikemukakan oleh Amstrong's (2009:532) "performance is measured in several dimension in term of the competencies required to achieve the target level of performace in a particular job or at a particular level in organization". Kinerja adalah evaluasi dari hasil perilaku seseorang ini meliatkan 
penentuan mengenai seberapa baik dan buruk seseorang dalam menyelesaikan sebuah tugas.

Selain itu Colquitt (2009:37) dalam bukunya juga mengatakan "task performace is the set of explicit obligations that an employee must fulfill to receive compensationand continued employment". Pengertian tersebut menunjukan bahwa kinerja adalah seperangkat kewajiban yang jelas yang harus dipenuhi atau dilakukan karyawan untuk mendapatkan kompensasi dan kelajutan pekerjaan

Dari beberapa pendapat ahli tersebut diatas, dapat disimpulkan bahwa evaluasi kinerja adalah penilaian yang dilakukan secara sistematis untuk mengetahui hasil pekerjaan karyawan dan kinerja organisasi. Oleh sebab itu evaluasi kinerja adalah suatu metode dan proses penilaian pelaksanaan tugas (performance) seseorang atau sekelompok orang atau unit-unit kerja dalam satu perusahaan atau organisasi sesuai dengan standar kinerja atau tujuan yang ditetapkan lebih dahulu. Dalam pelaksanaan evaluasi kinerja tenaga pendidik dibutuhkan adanya rambu-rambu/konsep evaluasi. Konsep evaluasi disini mencakup syarat sistem evaluasi, prinsip pelaksanaan, aspek yang dinilai dalam evaluasi dan perangkat pelaksanaan evaluasi.

Mengingat pentingnya kinerja guru tersebut, maka tentang guru dibuat peraturan yaitu: 1) Pada BAB XI pasal 39 ayat (2) mengatakan bahwa pendidik merupakan tenaga profesional yang bertugas merencanakan dan melaksanakan proses pembelajaran, menilai hasil pembelajaran, melakukan pembimbingan dan pelatihan serta melakukan penelitian dan pengabdian kepada masyarakat, terutama bagi pendidik pada perguruan tinggi. 2) Undang-Undang No 14 tahun 2005 pasal 20, tugas atau kewajiban guru antara lain:

a. Merencanakan pembelajaran dan mengevaluasi proses pembelajaran yang bermutu, serta menilai dan mengevaluasi hasil pembelajaran.

b. Meningkatakan dan mengembangkan kualifikasi akademik dan kompetensi secara berkelanjutan sejalan dengan perkembangan ilmu pengetahuan, teknologi dan seni.

c. Bertindak objektif dan tidak diskriminatif atas dasar pertimbangan jenis kelamin, agama atau latar belakang keluarga dan status sosial ekonomi peserta didik dalam pembelajaran.

d. Menjunjung tinggi peratiran perundang-undangan, hukum dan kode etik guru serta nilai-nilai agama dan etika.

Dalam konteks evaluasi guru yang menjadi objek evaluasi ialah guru atau tenaga pendidik tersebut. Evaluasi tersebut menganalisis seberapa besar persentase kinerja guru dalam melaksanakan tugasnya. Pada Peraturan Menteri Negara Pendayagunaan Aparatur Negara dan Reformasi Birokrasi No. 16 Tahun 2009 mengatakan bahwa penilaian kinerja guru adalah penilaian yang dilakukan terhadap setiap butir kegiatan tugas utama guru dalam rangka pembinaan karir, kepangkatan, dan jabatannya. Agar kinerja guru profesional bisa sesuai dengan tujuan pembelajaran dan tujuan pendidikan yang diharapkan, perlu diperhatikan prinsip-prinsip peningkatan kemampuan profesional guru sebagai 
berikut: 1) Peningkatan kamampuan profesional guru merupakan upaya membantu guru yang belum profesional menjadi profesional. Peningkatan kemampuan profesional merupakan bantuan agar guru dapat profesional dalam pembelajaran. 2) Peningkatan kemampuan profesional guru tidak benar bila hanya diarahkan kepada pembinaan kemampuan pegawai. Guru yang profesional mempunyai dua ciri yaitu tingkat abstraksi yang tinggi dan tingkat komitmen yang tinggi.

Peningkatan kinerja guru berbanding lurus dengan mutu yang dihasilkan oleh sekolah, dengan sumber daya manusia yang berkualitas salah satu penentu dalam perbaikan mutu bagi peserta didik. Menurut Prim Masrokan dalam bukunya Manajemen Mutu sekolah (2013:135) mutu dalam pendidikan meliputi mutu input, proses, output dan outcome. Input pendidikan dinyatakan bermutu apabila siap berproses yang sesuai dengan standar minimal nasional dalam bidang pendidikan. Proses pendidikan dapat dinyatakan bermutu apabila mampu menciptakan suasana pembelajaran yang aktif, kreatif, inovatif dan menyenangkan sehingga tujuan pendidikan bisa tercapai dengan baik. Output, dinyatakan bermutu apabila hasil belajar yang dicapai peserta didik baik, outcome dinyatakan bermutu apabila lulusan cepat terserap dalam dunia kerja maupun lembaga-lembaga yang membutuhkan lulusan tersebut.

\section{METODE}

Tujuan penelitian ini untuk mengevaluasi kinerja Guru dalam peningkatan mutu pendidikan terhadap 1) Penilaian kinerja guru yang terkait dengan perencanaan proses pembelajaran bagi guru mata pelajaran, 2) Penilaian kinerja guru dalam melaksanakan proses pembelajaran di dalam kelas, 3) Kinerja yang terkait dengan penilaian atau evaluasi hasil pembelajaran di dalam kelas bagi guru mata pelajaran, 4) Peningkatkan mutu melalui kinerja guru di Pondok Pesantren Al Kenaniyah Jakarta Timur. Penelitian ini bersifat kualitatif yang menggunakan metode Discrepancy Model of Evaluation (DEM).

Pengumpulan data yang digunakan yaitu kuantitatif dan kualitatif. Data kuantitaif untuk menghitung skor checklist berjumlah 76 butir sedangkan data kualtitaif dikumpulkan dengan wawancara, observasi dan dokumentasi yang dilakukan peneliti. Teknik analisis data yang digunakan dalam penelitian ini meliputi analisis data kuantitatif yakni dengan statistika deskriptif dan analisis data kualitatif.

\section{HASIL DAN PEMBAHASAN}

\section{Evaluasi Kinerja Guru dalam Perencanaan Pembelajaran}

Berikut ini adalah hasil dari evaluasi kinerja guru berdasarkan data cheklist yang dilakukan peneliti. Dalam efektifnya kerja guru merencanakan pembelajaran akan dijabarkan melalui tabel berikut : 
Tabel 1. Hasil Evaluasi dalam Perencanaan Pembelajaran

\begin{tabular}{lcc}
\hline Ranah Komponen & Nilai & Interpretasi \\
\hline Rumusan Standar kompetensi & $97 \%$ & Sangat baik \\
Rumusan Kompetensi dasar & $97 \%$ & Sangat baik \\
Indikator & $97 \%$ & Sangat Baik \\
Bahan ajar & $94,5 \%$ & Sangat Baik \\
Langkah pembelajaran & $75 \%$ & Baik \\
Media dan sumber pembelajaran & $94,5 \%$ & Baik \\
\hline \multicolumn{1}{c}{ Hasil rata-rata } & $92,5 \%$ & Sangat Baik
\end{tabular}

Dalam kompetensi profesional guru kinerja perencanaan pembelajaran merupakan salah satu hal yang menunjang guru sebelum memulai pembelajaran. Perencanaan pembelajaran adalah indikator proses yang dapat secara objektif dijadikan salah satu indikator untuk mengukur kinerja guru. Perencanaan pembelajaran meliputi tujuan, sasaran, metode, penggunaan media dan proses. Tujuan pembelajaran memberikan arahan tentang kemampuan yang akan di capai melalui pembelajaran. Hal ini sesuai dengan pendapat yang di kemukakan Barlow dalam buku Psikologi Pendidikan karya Muhibin Syah (1999: 229) kinerja guru merupakan kemampuan seorang guru dalam melaksanakan kewajiban-kewajiban secara bertanggung jawab dan layak, guru merupakan tenaga profesional yang bertugas merencanakan, melaksanakan dan menilai kegiatan akademik sekaligus dalam kegiatan mengajar. Berdasarkan hasil evaluasi komponen kinerja guru dalam perencanaan dapat dijabarkan sebagai berikut: Dalam perumusan standar kompetensi memperoleh $97 \%$, kompetensi dasar $97 \%$, indikator $97 \%$, bahan ajar 94, 5\% dan media pembelajaran 94,5\% dengan kualifikasi sangat baik. Sedangkan langkah pembelajaran memperoleh 75 \% berkualifikasi baik. Dari hasil keseluruhan kinerja guru dalam perencanaan mempunyai presentase sangat baik karena pada awal tahun ajaran baru kepala sekolah akan memeriksa administrasi yang dibuat oleh guru sebelum memulai pembelajaran. Hal tersebut juga di dukung dengan wawancara guru yang melaksanakan proses perencanaan pembelajaran dengan membuat dokumen RPP dan silabus secara lengkap sebelum memulai pelaksanaan pembelajaran sesuai dengan mata pelajaran yang di ampu setiap guru. Kinerja Guru Yayasan Al Kenaniyah mengelola administrasi perencanaan pembelajaran di nilai tidak mempunyai hambatan karena secara umum guru memenuhi semua kriteria evaluasi dan menjadikan bahan pedoman mengajar. 


\section{Evaluasi Kinerja Guru dalam Pelaksanaan Pembelajaran}

Pada tahap pelaksanaan, aktivitas belajar mengajar berpedoman pada persiapan pengajaran yang dibuat. Pemberian bahan pelajaran disesuaikan dengan urutan yang telah diprogram secara sistematis dalam tahap persiapan. Langkahlangkah pelaksanaan pembelajaran meliputi yaitu: kegiatan awal, kegiatan inti, dan kegiatan akhir. Kegiatan awal merupakan kegiatan tatap muka antara guru dan siswa. Dalam kegiatan ini guru memberi petunjuk, pengarahan dan apersepsi, atau dapat juga dengan menyampaikan tujuan yang akan dicapai dan memberikan beberapa pertanyaan (pretest). Dalam kegiatan inti, guru menjelaskan materi dengan menggunakan pendekatan, metode dan teknik yang sudah ditentukan. Sedangkan dalam kegiatan akhir dapat berupa umpan balik dan penilaian. Berikut hasil dari data cheklist yang peneliti lakukan di Yayasan AlKenaniyah.

Tabel 2. Kinerja Guru Tentang Pelaksanaan Pembelajaran

\begin{tabular}{lcc}
\hline Komponen & Nilai Akhir & Interpretasi \\
\hline Kegiatan pendahuluan & $79,61 \%$ & Baik \\
Sikap guru & $62,5 \%$ & Cukup \\
Penguasaan Belajar & $67,5 \%$ & Cukup \\
Mengelola Interaksi Kelas & $75 \%$ & Baik \\
Keterkaitan Metode & $57,5 \%$ & Cukup \\
Melakukan Refleksi & $80 \%$ & Baik \\
\hline \multicolumn{1}{c}{ Hasil Rata-rata } & $70,35 \%$ & Baik
\end{tabular}

Berdasarkan hasil dari evaluasi instrumen checklist pelaksanaan pembelajaran yang terkait dengan kinerja guru berpresentasi baik dengan perolehan presentase70,35 \%. Hal ini sesuai dengan komponen yang ada pada Dirjen Depdikbud (1998: 1) yaitu : 1) kegiatan pembelajaran 2) penggunaan metode, media dan bahan latihan, 3) interaksi dengan siswa, 4) metode pengajaran, 5) sikap mendorong dan menciptakan ketertiban siswa dalam kelas, 6) penguasaan mata pelajaran, 7) pengorganisasian waktu, ruang, bahan perlengkapan dan 8) evaluasi hasil belajar. Tetapi, dalam pelaksanaan pembelajaran mempunyai kekurangan yang ditemukan peneliti selama observasi yaitu kinerja guru dalam menerapkan metode pembelajaran. Siswa di tuntut aktif dan guru diharuskan memberikan stimulus agar siswa dapat mengembangkan daya fikirnya. Metode yang digunakan guru secara umum adalah metode ceramah, guru menjadi central dalam pembelajaran sedangkan siswa hanya mendengar tidak berpartisipasi dalam kegiatan pembelajaran, seperti mencari sumber lain tentang materi mata pelajaran. Pendekatan pembelajaran harus menciptakan suasana teaching-learning yang dapat menumbuhkan rasa dari tidak tahu menjadi tahu dan guru memposisikan diri 
sebagai pelatih atau fasilitator. Kebiasaan metode pembelajaran yang sekarang ini dilakukan siswa menerima informasi secara pasif, seperti mencatat, mendengar yang seharusnya diubah pada pola produktif. Dan disinilah peran guru sebagai fasilitator dikelas harus mempunyai metode yang diinginkan kurikulum dengan metode bervariasi yaitu dibuka peluang seluas-luasnya bagi anak untuk mengembangkan gagasan kreatif supaya anak selalu aktif. Secara umum, hasil evaluasi kinerja guru dalam pelaksanaan pembelajaran berkualifikasi baik, di dukung dengan wawancara guru yaitu sebelum memulai pembelajaran di kelas: guru melakukan kegiatan pendahuluan, menanyakan kabar, apersepsi,memberi contoh tentang suatu tindakan terlebih dahulu yang berhubungan dengan materi pembelajaran yang akan di pelajari hari itu.

\section{Kinerja Guru dalam Evaluasi Hasil Pembelajaran}

Penilaian hasil belajar adalah kegiatan atau cara yang ditujukan untuk mengetahui tercapai atau tidaknya tujuan pembelajaran dan juga proses pembelajaran yang telah dilakukan. Pada tahap ini seorang guru di tuntut memiliki kemampuan dalam menentukan pedekatan dan cara-cara evaluasi, penyusunan alat-alat evaluasi, pengolahan dan penggunaan hasil evaluasi. Berikut ini tabel komponen kinerja guru dalam evaluasi hasil belajar peserta didik.

Tabel 3. Kinerja Guru terkait Evaluasi Pembelajaran

\begin{tabular}{lcc}
\hline Komponen & Nilai Akhir & Interpretasi \\
\hline $\begin{array}{l}\text { Guru Merancang alat evaluasi untuk } \\
\text { mengukur kemajuan dan keberhasilan belajar } \\
\text { peserta didik }\end{array}$ & $98,3 \%$ & Sangat Baik \\
$\begin{array}{l}\text { Guru menggunakan berbagai strategi dan } \\
\text { metode penilaian untuk memantau kemajuan } \\
\text { dan hasil belajr peserta didik }\end{array}$ & $98,3 \%$ & Sangat Baik \\
$\begin{array}{l}\text { Guru memanfaatkan berbagai hasil penilaian } \\
\text { untuk memberikan umpan balik bagi peserta } \\
\text { didik tentang kemajuan belajarnya dan } \\
\text { bahan penyusunan rancangan pembelajaran } \\
\text { selanjutnya }\end{array}$ & $85,5 \%$ & Baik \\
\begin{tabular}{l} 
Pengeloaan Hasil Penilaian \\
\multicolumn{1}{c}{ Hasil Rata-rata }
\end{tabular} & $85,4 \%$ & Baik \\
\hline
\end{tabular}

Berdasarkan hasil data checklist guru komponen evaluasi yang pertama adalah guru merancang alat evaluasi untuk mengukur kemajuan dan keberhasilan belajar peserta didik yang mendapatkan prosentase $81,5 \%$ kinerja guru tersebut dinilai baik. Hal ini sesuai dengan apa yang tertulis dalam RPP guru mempunyai 
alat evaluasi dari tes lisan, tulis dan mempunyai data hasil analisis penilaian. Komponen kedua guru menggunakan berbagai strategi dan metode penilaian untuk memantau kemajuan dan hasil belajar peserta didik dalam mencapai kompetensi tertentu hasil analisis menunjukan 81,5\% guru mempunyai kinerja baik. Komponen ketiga yaitu guru memanfaatkan berbagai hasil penilaian untuk memberikan umpan balik bagai peserta didik, dengan jumlah presentase $85,5 \%$ artinya berkinerja baik. Komponen keempat yaitu pengelolaan hasil penilaian dan memperoleh presentase $80 \%$ artinya berkinerja baik. Hasil tersebut sesuai yang dikemukakan oleh Grasser dalam buku Nana Sudjana (1989: 18) ada empat hal yang harus dikuasai guru diantaranya : 1) kemampuan menguasai bahan pelajaran, 2) kemampuan mendiagnosis tingkah laku siswa, 3) kemampuan melaksanakan proses pengajaran dan 4) kemampuan mengukur hasil belajar siswa. Evaluasi pembelajaran juga digunakan sebagai umpan balik yang harus dilaporkan guru kepada Kepala sekolah dan wali murid untuk mengetahui perkembangan peserta didik tersebut. Hal senada juga di ungkapkan dalam wawancara guru, bahwa guru merancang alat evaluasi bagi siswa melalui ulang harian, ulangan tengah semester dan ulangan akhir semester dan sudah tertera pada Rencana Pembelajaran.

\section{Pengaruh disiplin Kerja Terhadap Kinerja guru}

Disiplin kerja seorang guru merupakan kepatuhan dan upaya-upaya perilaku untuk bekerja sesuai dengan peraturan-peraturan yang berlaku. Disiplin yang baik akan meningkatan kinerja guru sehingga beban kerja dan tanggung jawabnya dapat dikerjakan dan diselesaikan dengan baik dan tidak menggangu proses belajar di dalam kelas. Berikut adalah tabel kriteria displin kerja guru.

Tabel 4 Disiplin kerja guru

\begin{tabular}{lcc}
\hline \multicolumn{1}{c}{ Komponen } & Nilai Akhir & Interpretasi \\
\hline Patuh terhadap ketentuan & $75 \%$ & Baik \\
Kesediaan melakukan pekerjaan & $87,5 \%$ & Baik \\
$\begin{array}{l}\text { Tanggung jawab melaksanakan } \\
\text { tugas }\end{array}$ & $75 \%$ & Baik \\
\hline \multicolumn{1}{c}{ Hasil Rata-rata } & $79,2 \%$ & Baik \\
\hline
\end{tabular}

Kriteria yang terakhir adalah disiplin kerja, karena disiplin kerja dapat memberikan ketepatan dalam pelaksanaan tugas pokok guru. Menurut Gordon (1996: 3) disiplin kinerja adalah sebagai perilaku dan tata tertib yang sesuai dengan peraturan dan ketetapan guru juga berdampak penting bagi terciptanya proses pembelajaran yang kondusif, wajib bagi guru mentaati dan mematuhi seluruh peraturan yang berlaku. Disiplin kerja guru dikaitkan dengan tugas-tugas mereka di 
sekolah agar pekerjaan dapat dilaksanakan secara efektif dan efisien. Kinerja guru di pengaruhi oleh disiplin kerja meliputi patuh terhadap ketentuan yang memperoleh presentase $75 \%$ kinerja baik, kedua kesediaan melakukan pekerjaan yang mendapatkan 87,5\% kinerja baik dan ketiga tanggung jawab tugas mendapatkan 75\% kinerja baik. Berdasarkan Hasil evaluasi disiplin guru menunjukan kinerja baik ,tetapi ada kriteria yang belum terpenuhi yaitu kurang disiplin nya guru datang kesekolah, dan sering kali guru tidak datang karena terdapat urusan di luar sekolah hal ini bila terus menerus sering dilakukan akan memberikan efek negatif kepada peserta didik.

Berdasarkan hasil analisis di atas tugas maupun fungsi guru tidak dapat dipisahkan. Dan hal tersebut di sejajarkan dengan Undang- Undang No 20 Tahun 2003 peran guru adalah sebagai pendiidk, engajar, pelatih, penilai dan pengevaluasi peserta didik. Evaluasi guru perencanaan, pelaksanaan, penilaian dan disiplin kerja yang berada dalam Yayasan Al Kenaniyah mempunyai kinerja baik, hal ini berpengaruh kepada mutu pendidikan juga berpresentase baik. Selain di dukung dengan kinerja guru yang baik, Yayasan Al Kenaniyah mempunyai fasilitas dan gedung yang memadai. Mutu pendidikan yang baik dapat dilihat dari peserta didik yang di Yayasan Al Kenaniyah sering mengikuti olimpiade tingkat provinsi ataupun Nasional pada bidang SAINS juga olahraga. Namun, terdapat beberapa aspek yang menjadi hambatan dalam pelaksanaan tugas-tugas guru meliputi: Aspek pertama, Pengelolaan guru terhadap kelas termasuk penggunaan jam belajar yang efektif saat di dalam kelas. Hasil observasi peneliti, guru kurang memahami pribadi masingmasing peserta didik dikelas. Aspek kedua, metode pembelajaran yang dilakukan cenderung belum melibatkan siswa untuk aktif di kelas. Pada kenyataanya, metode yang digunakan guru sangat berpengaruh dalam penyampaian materi pelajaran terhadap siswa. Sehingga diperlukan penyampaian yang baik, tidak menjenuhkan, dan memancing daya fikir yang kreatif dari siswa. Aspek ketiga, guru belum disiplin untuk datang tepat waktu di sekolah. Hal tersebut merupakan hambatan yang harus diperbaiki sesuai dengan pendapat Sardiman (2016:19) tentang kompetensi profesional guru harus memenuhi berbagai syarat diantaranya: 1)mengusai bahan dan pengelola kelas, 3) menguasai sumber dan media belajar, 4) mengelola interaksi belajar, 5) melakukan penilaian belajar.

Untuk meningkatkan mutu pendidikan diperlukan guru yang baik dalam memberikan pembelajaran bagi peserta didik. Beberapa tindakan korektif dalam peningkatan mutu pendidikan di Yayasan Al Kenaniyah yang sudah dilakukan antara lain 1)Mengadakan supervisi secara rutin yang dilakukan oleh Kepala Sekolah pada tiap instasi pendidikan Madrasah Aliyah dan Madrasah Tsanawiyah. Supervisi akademik merupakan kegiatan pembinanan yang direncanakan dengan memberi bantuan teknis kepada guru dalam melaksanakan proses pembelajaran atau mendukung proses pembelajaran yang bertujuan untuk meningkatkan kemampuan guru dalam menjalankan tugas dan tanggung jawabnya sehingga dapat meningkatkan pembelajaran secara efektif. 2) Mendirikan komite sekolah yang mempunyai tujuan mempermudah komunikasi antara guru dengan orang tua 
murid atau pun masyarakat. Komite sekolah terdiri dari beberapa orang tua murid, tokoh masyarakat sekitar Yayasan Al Kenaniyah, Pimpinan Pondok Pesantren, Alumni. Tugas komite sekolah dalam peningkatan mutu pendidikan antara lain : mendorong hubungan baik yang terjalin antara Yayasan Al Kenaniyah dengan masyarakat, mendukung kelancaran kegiatan pendidikan, juga membantu pendanaan untuk mendanaan fasilitas yang ada di Al Kenaniyah. Sekolah yang berada di bawah naungan Yayasan Al kenaniyah merupakan sekolah swasta yang minim bantuan dari pemerintah sehingga diperlukan pendanaan yang berasal dari luar untuk pengadaan fasilitas yang ada di Al Kenaniyah.

\section{PENUTUP}

Kesimpulan: Berdasarkan hasil evaluasi dan pembahasan kinerja guru meliputi kegiatan perencanaan, pelaksanaan, evaluasi pembelajaran dan di dukung oleh disiplin kerja guru yang mempunyai tanggung jawab dalam melaksanakan tugas dan tanggung jawabnya. Kinerja guru dalam perencanaan pembelajaran memperoleh 92,5\%, kinerja guru dalam pelaksanaan pembelajaran memperoleh $70,35 \%$, kinerja guru dalam penilaian pembelajaran 91,9\%, disiplin kerja guru memperoleh 79, 2\%. Terdapat beberapa hambatan yang dapat menghambat kinerja guru diantaranya yaitu: pelaksanaan pembelajaran metode yang digunakan guru belum sepenuhnya mendukung peserta didik untuk dapat menstimulus daya berfikir agar lebih berpartisipasi dalam pembelajaran. Kinerja guru juga akan terhambat apabila guru tidak hadir tepat waktu. Dalam usaha untuk peningkatan mutu pendidikan diperlukan pembaharuan untuk terus memperbaiki kekurangan.

Rekomendasi: 1) Rutin melakukan supervisi akademik yang dapat dilakukan oleh pimpinan terkait. Adanya pemberdayaan guru yang dapat dilakukan dengan memfasilitasi guru dalam seminar atau pelatihan yang rutin dilakukan bagi semua guru mata pelajaran. 2) Perekrutan guru dengan latar belakang pendidikan yang sesuai dengan mata pelajaran. 3).Melaksanakan program MGWP (Musyawarah Guru mata Pelajaran). MGWP adalah forum kegiatan profesional guru mata pelajaran sejenis. Dengan MGWP ini diharapkan guru dapat meningkatkan metode pembelajaran, teknis edukatif tentang IPTEK yang bisa di gunakan dalam pembelajaran di kelas, berbagi informasi, dan meningkatkan profesionalisme guru.

\section{DAFTAR RUJUKAN}

Amstrong's. Human Resourses Management Practice. London and Philadephia: British Library Cataloguing, 2009

Arifin. Zainal. Evaluasi Pembelajaran. Bandung: PT Rosda Karya, 2009

Colquitt, Jason. A Jeffery A Lepine, Michael J Wesson. Organizational Behavior: Improving Performanceand Commitment in the Workplace. New York: McGrawHill International Edition, 2009 
Dirjen Depdikbud. Proyek Peningkatan Guru, Alat Penilaian Kemampuan Guru Jakarta: Depdibud, 1998

George, Jennifer. M Gareth R Jones, Understanding And Managing Organizational Behavior. New Jersey: Pearson Education, Inc Prentice Hall, 2012

Mutohar, Prim Masrokan.Manajemen Mutu Sekolah. Jogjakarta:Ar Ruzz Media.2013.

Provus, Malcom The Disrepancy Evaluation Model dalam Presentasi makalah Kumahani Bt Ku Mat Desa, Penerjemah: Jamil Ahmad, 2015

Sardiman. Interaksi dan Motivasi Belajar Mengajar. Jakarta: PT Bumi Aksara.2016

Slocum, Herriegel. Organizational behavior. USA: South Western, 2011

Staw, Barry. Research In Organizational Behavior. New York: Elsevier Ltd, 2003

Stufflebeam, Daniel L. George F Mandaus, Thomas Kellaghan. Evaluation Models Viewpoints on Educational And Human Services Evaluation Secon Edition. New York: Kluwe Academic Publishers Dordrecht, 2002.

Sudjana, Nana. Dasar-Dasar Proses Belajar Mengajar. Bandung:Sinar Baru Algensindo. 1989.

Syah, Muhibin. Psikologi Pendidikan dengan Pendekatan Baru.Bandung: Remaja Rosdakarya,1999

Torrington, Derek. Laura Hail, Stepen Taylor. Human Resource Management Sixth edition, Englan: Pretice Hall, 2005 